\title{
PENINGKATAN POPULASI TERNAK SAPI DAN PENGETAHUAN PETANI DALAM PEMBUATAN PUPUK ORGANIK DI KELOMPOK TANI SUMBER REZEKI DESA BUALO KABUPATEN BOALEMO
}

\author{
Nurdin $^{1 *}$, Fitriah S. Jamin ${ }^{1}$, Siswatiana R. Taha², Amelia Murtisai ${ }^{3}$, \\ ${ }^{1}$ Jurusan Agroteknologi, Fakultas Pertanian, Universitas Negeri Gorontalo, Gorontalo, Indonesia \\ ${ }^{2} J u r u s a n$ Peternakan, Fakultas Pertanian, Universitas Negeri Gorontalo, Gorontalo, Indonesia \\ ${ }^{3} J u r u s a n$ Agribisnis, Fakultas Pertanian, Universitas Negeri Gorontalo, Gorontalo, Indonesia \\ *Penulis Korespodensi: nurdin@ung.ac.id
}

\begin{abstract}
Abstrak
Peningkatan populasi ternak sapi dapat dilakukan melalui kegiatan Inseminasi Buatan (IB) yang diharapkan juga dapat meningkatkan hasil kotoran ternak (feases) sebagai sumber bahan baku pupuk organik. Kegiatan ini bertujuan untuk: (1) meningkatkan populasi ternak sapi sebagai penghasil bahan baku pupuk organik, dan (2) meningkatkan pengetahuan Kelompok Tani Sumber Rezeki dalam pembuatan pupuk organik. Kegiatan ini dimulai bulan Maret sampai Agustus 2019 di Desa Bualo Kecamatan Paguyaman Kabupaten Boalemo. Kegiatan ini terdiri dari: (1) Kegiatan IB terhadap sapi induk yang sehat dan siap (masa birahi) oleh inseminator., dan (2) Pembuatan pupuk organik yang dilakukan melalui kegiatan pelatihan dan pendampingan. Sebelum dan sesudah pelatihan, dilakukan tes tingkat pengetahuan tentang pupuk organik kepada 25 orang peserta pelatihan yang dianalisis menggunakan Skala Likert. Bahan pembuatan pupuk organik meliputi: limbah jagung, bungkil kakao, feases, urin, EM4, gula dan air. Semua bahan dicampur merata dalam bak fermentasi, ditutup dengan terpal dan dibiarkan selama 3 minggu. Selama kegiatan berlangsung, antusias peserta dalam mengikuti seluruh kegiatan sangat tinggi dengan capaian 100\%. Kegiatan IB telah menghasilkan sebanyak 12 ekor sapi bunting. Kegiatan pelatihan dan pendampingan kepada petani di Kelompok Tani Sumber Rezeki telah mampu meningkatkan pengetahuan tentang pembuatan pupuk organik dengan capaian sebesar $88,0 \%$ dari total peserta pelatihan.
\end{abstract}

Kata kunci: Populasi, Sapi, Inseminasi Buatan, Pengetahuan, Pupuk Organik.

\begin{abstract}
Increasing cattle population can be done through Artificial Insemination (IB) activities which are also expected to increase livestock manure yields (feases) as a source of raw material for organic fertilizer. This activity aims to: (1) increase the population of cattle as a producer of raw materials for organic fertilizer, and (2) increase the knowledge of Sumber Rezeki Farmer Groups in making organic fertilizer. This activity began in March to August 2019 in Bualo Village, Paguyaman District, Boalemo Regency. This activity consists of: (1) IB activities towards healthy and ready mother cows (incubation period) by inseminators, and (2) Making organic fertilizer carried out through training and mentoring activities. Before and after the training, a knowledge level test about organic fertilizer was conducted on 25 trainees who were analyzed using a Likert Scale. Organic fertilizer manufacturing materials include: corn waste, cocoa meal, feases, urine, EM4, sugar and water. All ingredients are mixed evenly in a fermentation tank, covered with tarpaulin and left for 3 weeks. During the activity, participants' enthusiasm in participating in all activities was very high with $100 \%$ achievement. IB activities have produced as many as 12 pregnant cows. Training activities and assistance to farmers in the Sumber Rezeki Farmer Group have been able to increase knowledge about making organic fertilizer with an achievement of $88.0 \%$ of the total training participants.
\end{abstract}

Keywords: Population, Cow, Artificial Insemination, Knowledge, Organic Fertilizer.

\section{PENDAHULUAN}

Desa Bualo Kecamatan Paguyaman Kabupaten Boalemo Provinsi Gorontalo menjadi salah satu dari 40 desa pilot dan kawasan Desa Prioritas Nasional/KPPN di Indonesia yang telah ditetapkan oleh Bappenas dan Kementrian Koordinator Pembangunan Manusia dan Kebudayaan RI. Hal ini cukup beralasan karena berdasar data dalam RPJM Desa Bualo 2017-2022, masih terdapat kepala keluarga (KK) miskin sebesar 43,30\% dan KK pra sejahtera sebesar 42,88\% dari total KK Desa Bualo (Pemerintah Desa Bualo, 2018). Padahal, potensi sumberdaya alam yang dimiliki desa ini sangat besar, terutama di sektor pertanian. 
Potensi sektor pertanian Desa Bualo sangat besar yang terdiri dari: sub sektor tanaman pangan berupa jagung dan padi, sub sektor perkebunan berupa kakao, kelapa dan kelapa sawit, serta sub sektor peternakan berupa sapi (Pemerintah Desa Bualo, 2018) dengan luas potensi lahan sebesar $2.560 \mathrm{Ha}$ (100\% dari total wilayah). Hal ini sejalan dengan laporan Nurdin et al. (2009) bahwa potensi lahan di wilayah Desa Bualo adalah sangat sesuai (S1) sampai sesuai marginal (S3) untuk tanaman jagung, kakao, kelapa dan hijauan makanan ternak dengan faktor pembatas kemiringan lereng, ketersediaan hara dan bahaya erosi. Seluruh lahan pertanian di desa ini sudah dimanfaatkan untuk pertanian tetapi produktifitas hasil pertanian masih rendah. Laporan BPS Kabupaten Boalemo (2018) menunjukkan bahwa produktifitas jagung baru sebanyak 5,2 ton/ha; padi sebanyak 4,5 ton/ha; kakao sebanyak 0,75 ton/ha dan kelapa baru sebanyak 0,82 ton/ha. Belum ada laporan resmi terkait jumlah ternak, terutama sapi potong di Desa Bualo walaupun faktanya di lapangan sudah dijumpai ternak sapi. Namun, menurut Kepala Desa Bualo bahwa jumlah populasi ternak sapi di desa ini diperkirakan sebanyak 50 ekor.

Salah satu permasalahan dalam peningkatan produksi dan produktifitas pertanian adalah minimnya ketersediaan pupuk anorganik (Urea dan Phonska). Selama ini petani mendapatkan pupuk berdasarkan kuota dan alokasi pupuk bersubsidi. Namun, kelangkaan pupuk tersebut masih terus terjadi dan menjadi faktor penghambat utama yang belum mendapatkan penanganan yang memadai, sehingga berkonsekuensi pada dalam peningkatan produksi dan produktifitas pertanian. Selain itu, penggunaan pupuk anorganik yang intensif telah menyebabkan penurunan kualitas tanah dan degradasi tanah. Hal ini sejalan dengan laporan Nuro et al. (2016) bahwa penurunan kesuburan tanah adalah akibat dari penggunaan pupuk kimia secara terus menerus yang terjadi karena penurunan sifat fisik, kimia, dan biologi tanah. Hal penting lainnya menunjukkan bahwa daya beli pupuk oleh petani setempat juga rendah yang dibuktikan dengan adanya keluhan dari kios pengecer pupuk tentang lambatnya pengambilan pupuk oleh petani karena minimnya dana yang dimiliki petani tersebut.

Potensi produksi pupuk organik sebagai alternatif subtitusi pupuk anorganik sangat besar berdasarkan kelimpahan bahan baku pupuk organik di Desa Bualo. Limbah pertanian sangat banyak dan umumnya dibiarkan begitu saja atau bahkan hanya dibakar di areal pertanaman, terutama limbah jagung. Limbah jagung selain daunnya kurang disukai ternak sapi karena jagung yang ditanam petani paling adalah varitas hibrida yang batang dan tongkolnya besar, sehingga sukar dicerna oleh ternak dan potensial menjadi sumber bahan baku pupuk organik. Namun demikian, jumlah populasi ternak penghasil feases dan urin masih sedikit di desa ini. Oleh karena itu, salah satu solusi untuk meningkatkan produksi feases dan urin adalah perbanyakan ternak sapi dan yang paling memungkin berdasarkan kondisi dan kemampuan masyarakat setempat melalui kegiatan Inseminasi Buatan (IB). Inseminasi buatan (IB) adalah penempatan semen pada saluran reproduksi secara buatan (Inounu, 2014). Sementara Sabran (2015) menyatakan bahwa inseminasi buatan (IB) atau kawin suntik adalah upaya memasukkan semen/mani ke dalam saluran reproduksi hewan betina yang sedang birahi dengan bantuan inseminator agar hewan bunting.

Kelompok Tani Sumber Rezeki merupakan salah satu kelompok tani di Desa Bualo yang mengembangkan komoditas jagung, kakao dan ternak sapi. Kelompok tani ini masih berstatus pemula dengan komoditi jagung yang mengelola lahan seluas 21,50 ha dan beranggotakan 14 orang yang diketuai oleh Bapak Edi Iskandar. Kelompok tani ini tergabung dalam Gapoktan Dwikarya dengan kode: 75.01.050.033.0022 dengan tanggal pembentukan: 02/03/2012 (Badan Koordinasi Penyuluhan Provinsi Gorontalo, 2019). Kelompok tani ini telah memiliki satu unit pengolahan pupuk organik (UPPO) bantuan dari Direktorat Pupuk dan Pestisida Ditjen Prasarana dan Sarana Pertanain Kementrian Pertanian RI pada tahun 2015.

Sampai tahun 2018, jumlah sapi yang dimiliki kelompok tani ini baru sebanyak 15 ekor saja. Padahal, bantuan ternak sapi melalui UPPO pada tahun 2015 tersebut sebanyak 10 ekor yang terdiri dari 9 ekor betina dan 1 ekor jantan, sehingga penambahan populasi ternak hanya sebesar $50 \%$ saja selama kurang lebih 4 tahun terakhir. Kondisi ini yang menjadi salah satu penyebab masih sangat rendahnya produksi pupuk organik. Padahal, potensi bahan baku untuk pembuatan pupuk organik sangat melimpah di Desa Bualo. Guna mengatasi masalah permasalahan tersebut, maka salah satu solusinya adalah pendampingan dan pemberdayaan petani melalui kelompok tani melalui peningkatan populasi ternak sapi melalui Inseminasi Buatan (IB) dan Pelatihan Pembuatan Pupuk Organik melalui Program Pengembangan Desa Mitra (PPDM) Unit Pengolahan Pupuk Organik (UPPO) Desa Bualo Kecamatan Paguyaman Kabupate Boalemo. Tujuan kegiatan ini adalah (1) meningkatkan populasi ternak sapi sebagai penghasil bahan baku pupuk organik, dan (2) meningkatkan pengetahuan Kelompok Tani Sumber Rezeki dalam pembuatan pupuk organik.

\section{BAHAN DAN METODE}

Upaya peningkatan populasi ternak sapi dan pengetahuan petani dalam pembuatan pupuk organik dilakukan melalui kegiatan IB dan pelatihan pembuatan pupuk organik dalam Program Pengembangan Desa Mitra (PPDM) tahun 2019 (tahun pertama). Kegiatan ini dilaksanakan di Desa Bualo Kecamatan Paguyaman Kabupaten Boalemo mulai bulan April sampai Agustus 2019. Peserta atau sasaran kegiatan ini adalah anggota Kelompok Tani Sumber Rezeki di Desa Bualo Kecamatan Paguyaman Kabupaten Boalemo. Metode yang digunakan dalam kegiatan ini terdiri dari:

\section{a. Inseminasi Buatan (IB)}

Kegiatan IB diawali dengan observasi melalui pengumpulan ternak sapi betina untuk dilakukan 
pemeriksaan kesehatan reproduksi oleh petugas inseminator yang dikoordinasikan oleh seorang dokter hewan setempat (kabupaten). Selanjutnya, hasil pemeriksaan kesehatan reproduksi tersebut terhadap induk betina sapi yang sudah siap bunting dan sehat langsung dilakukan proses IB, sementara terhadap induk betina sapi yang belum siap tapi sehat maka dilakukan sinkronisasi birahi sampai waktunya siap proses IB. Sapi induk yang sudah bunting selanjutnya diberi vitamin dan vaksinasi untuk menjamin kesehatan ternak tersebut selama proses kebuntingannya. Semua sapi induk yang melalui proses pemeriksaan kesehatan reproduksi dicatat dan direkam (recording) dalam kartu ternak sapi IB. Kegiatan IB dilakukan oleh seorang Inseminator setempat, Bapak I Made Aryana, SPt yang sudah bersertifikasi sebagai petugas Inseminator dan dibantu 5 orang mahasiswa bersama Tim PPDM. Selama proses tersebut ternak dan pemilik ternak mendapatkan pembinaan dan pendampingan dari tim PPDM.

\section{b. Pembuatan Pupuk Organik}

Pembuatan pupuk organik dilakukan melalui kegiatan pelatihan dan pemberdayaan anggota kelompok yang didahului dengan pemberian materi pelatihan kepada peserta yang menjadi sasaran dan dilanjutkan dengan praktek pembuatan pupuk organik. Sebelum dimulai pelatihan, terlebih dahulu dilakukan tes awal tingkat pengetahuan peserta tentang pupuk organik dengan metode survei menggunakan instrumen kuisioner kepada peserta pelatihan. Penilaian pengetahuan petani didasarkan pada lima item pertanyaan yang pernah dilakukan oleh Hadipurwanta dan Kuswanto (2017) dimodifikasi, yaitu: 1). Pengetahuan tentang pupuk organik; 2). Penggunaan pupuk organik; 3). Sumber bahan pupuk organik; 4). Kandungan hara dalam pupuk organik; dan 5). Jenis-jenis pupuk organik. Petani responden diminta memilih satu jawaban dengan cara mencentang atau melingkari pilihan jawaban huruf $a, b$, c, dan d pada instrumen. Pilihan jawaban peserta menunjukkan skor terendah sampai tertinggi. Jumlah peserta pelatihan adalah 25 orang (populasi), maka semua populasi karena $<100$ diambil sebagai sampel atau sampel jenuh (teknik non probability). Menurut Sugiyono (2013) sampel jenuh yaitu teknik penentuan sampel dengan cara mengambil seluruh anggota populasi sebagai responden atau sampel. Setelah itu pemberian materi dengan metode ceramah dan tanya jawab.

Praktek pembuatan pupuk organik dilakukan dengan pendekatan belajar sambil melakukan (learning by doing). Sebelum praktek dilakukan, terlebih dahulu dikumpulkan bahan-bahan dan peralatan yang akan digunakn dalam pembuatan pupuk organik. Bahanbahan yang digunakan meliputi: limbah pertanian (limbah jagung, bungkil kakao, feases, urin, EM4, gula (molase) dan air. Sementara itu, peralatan yang digunakan terdiri dari: mensin pencacah (copper), bak fermentasi, ember, terpal, dan sekop. Limbah pertanian terlebih dahulu dicacah dan dihaluskan dalam mesin pencacah dan dituangkan dalam bak fermentasi. Selanjutnya dicampur EM4 dengan gula dalam ember, kemudian semua bahan baku dicampur dan diaduk dalam bak fermentasi sampai merata dan percikkan dengan air sampai lembab merata. Setelah dipadatkan, tumpukan bahan pupuk organik ini ditutup dengan terpal dan dibiarkan selama 3 minggu untuk proses fermentasi dan pengomposan.

Setelah pelatihan dan praktek pembuatan pupuk organik dilaksanakan, maka dilakukan tes akhir tingkat pengetahuan peserta tentang pupuk organik. Metode yang digunakan sama seperti tes awal, yaitu metode survei dengan menggunakan instrumen kuisioner kepada peserta pelatihan. Sampai akhir sesi praktek pembuatan pupuk organik, jumlah peserta masih sama sebanyak 25 orang (populasi), maka semua populasi diambil sebagai responden (sampel jenuh). Analisis data meliputi: (1) Analisis validitas dengan mengkorelasikan skor tiap butir dengan skor total yang merupakan jumlah tiap skor butir., (2) Analisis reliabilitas secara internal consistency dengan menganalisis konsistensi butir-butir pertanyaan yang ada., (3) Analisis tabel untuk mengetahui hubungan antar beberapa variabel. Data yang dikumpulkan disusun dalam bentuk tabel kemudian dianalisis secara deskriptif untuk mengetahui persentase responden terhadap pengetahuan tentang pupuk organik. Analisis dilakukan menggunakan bantuan software SPSS 23.

Tingkat pengetahuan petani tentang pupuk organik dilakukan dengan analisis skor terhadap jawaban pertanyaan menggunakan alat ukur Skala Likert dan digambarkan dalam garis continuum. Jawaban petani responden pada kuesioner diberi skor seperti berikut: jawaban a (sangat tahu) nilai 4, jawaban b (tahu) nilai 3, jawaban c (tidak tahu) nilai 2, dan jawaban d (sangat tidak tahu) nilai 1. Interpretasi nilai skor dilakukan dengan menggunakan formulasi sebagai:

a) Nilai maksimal $=$ jumlah responden $\mathrm{x}$ jumlah pertanyaan $\mathrm{x}$ skor tertinggi.

b) Nilai minimal $=$ jumlah responden $\mathrm{x}$ jumlah pertanyaan $\mathrm{x}$ skor terendah.

c) Tingkat pengetahuan dan sikap adalah:

Total Nilai $=($ Jumlah skor yang diperoleh $/$ Skor tertinggi) $\mathrm{x} 100 \%$.

3. HASIL DAN PEMBAHASAN:

a. Peningkatan Populasi Ternak Sapi sebagai Penghasil Bahan Baku Pupuk Organik

Peningkatan populasi ternak sapi dilakukan dengan cara melaksanakan IB pada induk sapi yang sehat dan siap (masa birahi). Kegiatan IB tersebut diawali dengan sosialisasi bersama dengan kegiatan lainnya dalam PPDM Pengelola Unit Pengolahan Pupuk Organik (UPPO) Desa Bualo Kecamatan Paguyaman Kabupaten Boalemo. Kegiatan IB secara spesifik dimulai pada bulan Maret 2019 dan sebanyak 41 ekor sapi induk telah diperiksa kesehatan reproduksinya oleh Petugas Inseminator setempat (Tabel 1). 
Tabel 1. Hasil Pemeriksaan Kesehatan Reproduksi, Kebuntingan dan Hasil Inseminasi Buatan Ternak Sapi dalam PPDM di Desa Bualo, Tahun 2019.

\begin{tabular}{|c|c|c|c|c|c|c|c|c|c|c|c|}
\hline \multirow{3}{*}{$\begin{array}{l}\mathrm{N} \\
\mathrm{o}\end{array}$} & \multirow{3}{*}{$\begin{array}{c}\text { Nama } \\
\text { Pemilik } \\
\text { Ternak }\end{array}$} & \multirow{3}{*}{$\begin{array}{c}\text { Ras/ } \\
\text { Bangsa } \\
\text { Ternak }\end{array}$} & \multicolumn{3}{|c|}{$\begin{array}{c}\text { Pemeriksaan Kesehatan } \\
\text { Reproduksi }\end{array}$} & \multicolumn{2}{|c|}{$\begin{array}{l}\text { Inseminasi Buatan } \\
\text { (IB) }\end{array}$} & \multicolumn{3}{|c|}{ Pemeriksaan Kebuntingan } & \multirow{3}{*}{$\begin{array}{c}\text { Prediksi } \\
\text { Waktu } \\
\text { Kelahiran }\end{array}$} \\
\hline & & & \multirow{2}{*}{ Tanggal } & \multicolumn{2}{|c|}{ Diagnosa } & \multirow{2}{*}{ Tanggal } & \multirow{2}{*}{ Petugas } & \multirow{2}{*}{ Tanggal } & \multirow{2}{*}{ Diagnosa } & \multirow{2}{*}{ Vaksinasi } & \\
\hline & & & & Status ${ }^{*}$ & Sinkron & & & & & & \\
\hline \multirow[t]{2}{*}{1} & Iriyanto & Sapi & $30-3-019$ & SBSB & $\sqrt{ }$ & 01-04-019 & I Made & 01-05-019 & + & $\sqrt{ }$ & 01-12-019 \\
\hline & Podu & Bali & & & & & Aryana & & & & \\
\hline \multirow[t]{2}{*}{2} & Yusuf & Sapi & 30-3-019 & SBSB & $\sqrt{ }$ & 01-04-019 & I Made & 01-05-019 & + & $\sqrt{ }$ & 01-12-019 \\
\hline & Dede & Bali & & & & & Aryana & & & & \\
\hline \multirow[t]{2}{*}{3} & Edi & Sapi & 30-3-019 & SBSB & $\sqrt{ }$ & 01-04-019 & I Made & 01-05-019 & + & $\sqrt{ }$ & 01-12-019 \\
\hline & Iskandar & Bali & & & & & Aryana & & & & \\
\hline \multirow[t]{2}{*}{4} & Karim & Sapi & 30-3-019 & SB & - & - & I Made & 30-03-019 & + & $\sqrt{ }$ & $30-10-019$ \\
\hline & Rajak & Bali & & & & & Aryana & & & & \\
\hline \multirow[t]{2}{*}{5} & Yusuf & Sapi & $30-3-019$ & SB & - & - & I Made & $30-03-019$ & + & $\sqrt{ }$ & $30-10-019$ \\
\hline & Dede & Bali & & & & & Aryana & & & & \\
\hline \multirow[t]{2}{*}{6} & Wani & Sapi & $30-3-019$ & SBSB & $\sqrt{ }$ & 04-04-019 & I Made & 04-05-019 & + & $\sqrt{ }$ & 04-12-019 \\
\hline & Jalise & Bali & & & & & Aryana & & & & \\
\hline \multirow[t]{2}{*}{7} & Rustam & Sapi & $30-3-019$ & SBSB & $\sqrt{ }$ & 04-04-019 & I Made & 04-05-019 & + & $\sqrt{ }$ & 04-12-019 \\
\hline & Hasan & Bali & & & & & Aryana & & & & \\
\hline \multirow[t]{2}{*}{8} & Ramin $\mathrm{K}$. & Sapi & $30-3-019$ & SBSB & $\sqrt{ }$ & 04-04-019 & I Made & 04-05-019 & + & $\sqrt{ }$ & 04-12-019 \\
\hline & Musa & Bali & & & & & Aryana & & & & \\
\hline \multirow[t]{2}{*}{9} & Wardi & Sapi & 06-04- & SBSB & $\sqrt{ }$ & 09-04-019 & I Made & 09-05-019 & + & $\sqrt{ }$ & 09-12-019 \\
\hline & & Bali & 019 & & & & Aryana & & & & \\
\hline \multirow[t]{2}{*}{10} & Adam & Sapi & 06-04- & SBSB & $\sqrt{ }$ & 09-04-019 & I Made & 09-05-019 & + & $\sqrt{ }$ & 09-12-019 \\
\hline & Tahir & Bali & 019 & & & & Aryana & & & & \\
\hline \multirow[t]{2}{*}{11} & Mas Didi & Sapi & 13-04- & SBSB & $\sqrt{ }$ & 16-04-019 & I Made & $16-05-019$ & + & $\sqrt{ }$ & $16-12-019$ \\
\hline & & Bali & 019 & & & & Aryana & & & & \\
\hline \multirow[t]{2}{*}{12} & Osmar & Sapi & 13-04- & SBSB & $\sqrt{ }$ & 16-04-019 & I Made & $16-05-019$ & + & $\sqrt{ }$ & 16-12-019 \\
\hline & Rasyid & Bali & 019 & & & & Aryana & & & & \\
\hline
\end{tabular}

*SB = sudah bunting, SSB = Sehat Siap IB, SBSB = Sehat Belum Siap IB, TS = Tidak Sehat/Mandul/Pulia; + = Positif Bunting, - = Negatif Bunting

Selama kegiatan IB berlangsung, animo dan respon pemilik ternak sapi sangat tinggi yang ditunjukkan oleh banyaknya ternak sapi yang dibawa ke tempat pelaksanaan IB (Gambar 1 dan 2). Bahkan, pemilik ternak lain meminta kepada Tim PPDM dan petugas Inseminator agar kegiatan IB ini juga dilaksanakan di wilayahnya (dusun lain), mengingat jauhnya jarak dari tempat kegiatan IB dengan lokasi ternak sapi mereka berada. Berdasarkan alasan tersebut, maka tim PPDM dan Petugas Inseminator bersama Pemerintah Desa Bualo menyepakati untuk melaksanakan kegiatan IB dalam 3 (tiga) tahap, yaitu: tahap ke-1 pada tanggal 30 Maret 2019 berlokasi di Dusun Musayawarah, tahap ke2 pada tanggal 6 April 2019 berlokasi di Dusun Ilomonu, dan tahap ke-3 pada tanggal 13 April 2019 berlokasi di Dusun Beringin Jaya.

Hasil pemeriksaan terhadap sapi induk yang di IB pada bulan Mei 2019 sudah menunjukkan tanda-tanda positif bunting dan sampai bulan Juli 2019, sudah positif bunting (hamil) sebanyak 12 ekor sapi induk. Berapa keragaan (performance) sapi induk yang telah bunting disajikan pada Gambar 3. Hasil IB yang berhasil bunting sebanyak 12 ekor sapi induk atau baru sebesar 29,26\% dari total sapi induk (41 ekor) yang dilakukan pemeriksaan kesehatan reproduksi dan diinseminasi.
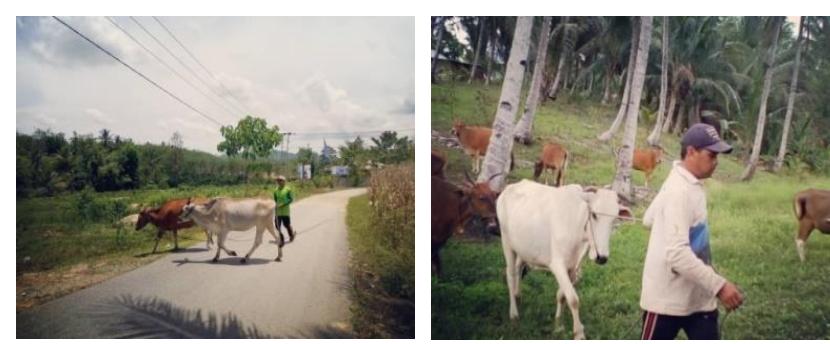

Gambar 1. Animo Pemilik Ternak Sapi Induk dalam Mengikuti Kegiatan IB Desa Bualo Kecamatan Paguyaman Kabupaten Boalemo.

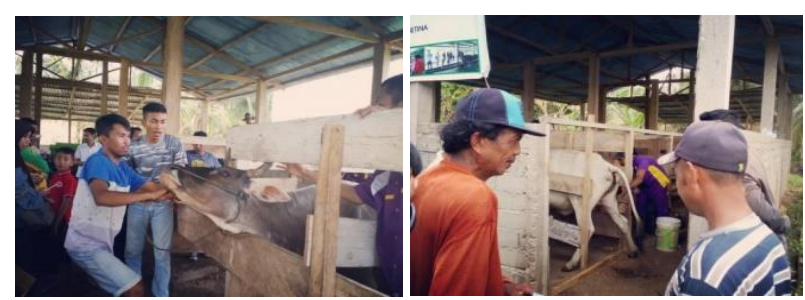

Gambar 2. Kegiatan IB oleh Petugas Inseminator bersama Tim PPDM dan Pemerintah Desa Bualo Kecamatan Paguyaman Kabupaten Boalemo.
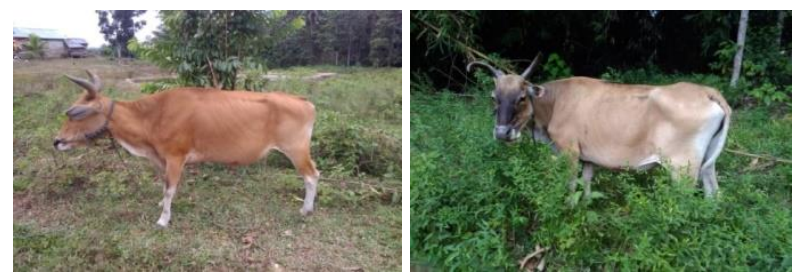

Gambar 3. Beberapa Hasil Kegiatan IB Sapi Induk yang Telah Bunting di Desa Bualo Kecamatan Paguyaman Kabupaten Boalemo. 
Banyak hambatan dan kendala yang ditemui di lapangan terkait pelaksanaan IB terhadap sapi induk yang akan diinseminasi antara lain: (1) Ketidak tahuan pemilik sapi bahwa setelah proses sinkronisasi sapi induk dan ditentukan waktu untuk proses IB, (2) Berhubung saat ini musim kemarau, maka banyak sapi yang tidak dikandangkan dan dicarikan tempat makan di lahan terbuka yang jaraknya cukup jauh dari tempat pelaksanaan IB., (3) Sulitnya proses komunikasi antara pemilik ternak dan Tim PPDM karena wilayah Desa Bualo belum terlayani jaringan telekomunikasi dan internet., dan (4) Banyak peternak yang bukan pemilik sapi dan hanya sebagai pemelihara dengan sistem bagi hasil anak ternak, sehingga harus mendapat persetujuan dari pemilik yang banyak tidak bermukim di desa ini. Namun demikian, dari semua hambatan dan kendala yang paling meninjol adalah ketidak tahuan pemilik sapi bahwa setelah proses sinkronisasi sapi induk dan ditentukan waktu untuk proses IB, tetapi pemilik tidak segera menghubungi petugas inseminator atau Tim PPDM, sehingga beberapa sapi induk sudah memasuki masa birahi justru kawin alami atau bahkan terlewatkan dan berakibat pada pengulangan kembali proses sinkronisasi. Menurut Hastuti (2008), tingkat keberhasilan IB salah satunya sangat dipengaruhi faktor akurasi deteksi birahi oleh para peternak dan ketrampilan inseminator. Sementara itu, Baba et al. (2015) melaporkan bahwa hambatan pelaksanaan IB menurut peternak terdiri dari sulitnya menghubungi insemantor, anak hasil IB sulit dibedakan dengan hasil kawin alam, belum diketahuinya waktu IB yang tepat serta trauma akibat kegagalan IB, sedangkan dari perspektif inseminator, faktor penghambat pelaksanaan IB adalah lokasi peternak yang jauh dan terpencar, rendahnya biaya operasional, sistem pemeliharaan semi intensif dan tidak ada kandang jepit.

\section{b. Peningkatan Pengetahuan Petani tentang Pupuk Organik}

Peningkatan pengetahuan petani tentang pupuk organik dilakukan dengan cara memberikan pelatihan dan pendampingan (praktek) pembuatan pupuk organik. Pelatihan tentang pupuk organik dan cara pembuatannya dilakukan dengan ceramah dan tanya jawab (Gambar 4). Kegiatan ini dilaksanakan di Aula Kantor Desa Bualo dengan peserta utama adalah anggota kelompok tani yang menjadi mitra PPDM, dan peserta tambahan dari warga Desa Bualo lainnya, terutama perangkat desa yang juga berprofesi sebagai petani setempat.

Sebelum dilakukan pemberian materi, maka dilaksanakan test awal pengetahuan peserta tentang pupuk organik dan hasilnya disajikan pada Tabel 2, 3 dan Tabel 4. Hasil pengujian validitas instrumen pengetahuan awal peserta terhadap pupuk organik menunjukkan bahwa instrumen yang digunakan untuk mengetahui tingkat pengetahuan awal peserta tentang pupuk organik di Desa Bualo Valid. Hal ini ditunjukkan oleh nilai korelasi mendekati 1 pada semua item yang diuji, yaitu antara $0,820-0,962$ dengan probabilitas korelasi rata-rata 0,000 (signifikan).
Tabel 2. Hasil Uji Validitas Instrumen Tingkat Pengetahuan Awal Peserta Sebelum Pelatihan.

\begin{tabular}{|c|c|c|c|c|}
\hline $\begin{array}{l}\mathbf{N} \\
\mathbf{o}\end{array}$ & $\begin{array}{c}\text { Korela } \\
\text { si } \\
\text { Antara }\end{array}$ & $\begin{array}{c}\text { Nilai } \\
\text { Korelasi } \\
\text { (Pearsons } \\
\text { Correlatio } \\
\text { ns) }\end{array}$ & $\begin{array}{l}\text { Probabilit } \\
\text { as } \\
\text { Korelasi } \\
\text { [sig.(2- } \\
\text { tailed)] }\end{array}$ & $\begin{array}{c}\text { Kesimpul } \\
\text { an }\end{array}$ \\
\hline 1 & $\begin{array}{l}\text { Item } \\
\text { No. } 1 \\
\text { dengan } \\
\text { Total }\end{array}$ & 0,820 & 0,000 & Valid \\
\hline 2 & $\begin{array}{l}\text { Item } \\
\text { No. } 2 \\
\text { dengan } \\
\text { Total }\end{array}$ & 0,876 & 0,000 & Valid \\
\hline 3 & $\begin{array}{l}\text { Item } \\
\text { No. } 3 \\
\text { dengan } \\
\text { Total }\end{array}$ & 0,882 & 0,000 & Valid \\
\hline 4 & $\begin{array}{l}\text { Item } \\
\text { No. } 4 \\
\text { dengan } \\
\text { Total }\end{array}$ & 0,882 & 0,000 & Valid \\
\hline 5 & $\begin{array}{l}\text { Item } \\
\text { No. } 5 \\
\text { dengan } \\
\text { Total }\end{array}$ & 0,962 & 0,000 & Valid \\
\hline
\end{tabular}

Hasil pengujian reliabilitas instrumen pengetahuan awal peserta tentang pupuk organik menunjukkan bahwa nilai Cronbach's Alpha sebesar 0,823. Hal ini menunjukkan bahwa instrumen yang digunakan untuk mengetahui pengetahuan awal peserta tentang pupuk organik di Desa Bualo Reliabel (Tabel 3).

Tabel 3. Nilai Cronbach's Alpha Instrumen Tingkat Pengetahuan Awal Peserta Sebelum Pelatihan. Tingkat Pengetahuan Awal Peserta

\begin{tabular}{cc}
\hline Cronbach's Alpha & N of Items \\
\hline .823 & 6 \\
\hline
\end{tabular}

Berdasarkan Tabel 4, rata-rata mayoritas peserta pelatihan tidak tahu terkait pengetahuannya tentang pupuk organik. Pesentase peserta yang tidak tahu dan bahkan sangat tidak tahu terkait pupuk organik sebesar $74.4 \%$. Sementara itu, peserta yang sudah tahu dan sangat tahu persentasenya hanya sebesar $25,6 \%$ saja.

Tabel 4. Persentase Jawaban Peserta tentang Pupuk Organik Sebelum Pelatihan.

\begin{tabular}{clccccc}
\hline \multirow{2}{*}{$\begin{array}{c}\text { N } \\
\text { o }\end{array}$} & \multirow{2}{*}{$\begin{array}{c}\text { Item } \\
\text { Pertanyaan }\end{array}$} & \multicolumn{3}{c}{ Persentase jawaban } & \multirow{2}{*}{ Jumla } \\
\cline { 2 - 5 } & STT & TH & T & ST & h \\
\hline 1 & $\begin{array}{l}\text { Pengertian } \\
\text { pupuk }\end{array}$ & 20 & 52 & 24 & 4 & 100 \\
\hline $\begin{array}{l}\text { organik } \\
2\end{array}$ & $\begin{array}{l}\text { Penggunaan } \\
\text { pupuk } \\
\text { organik }\end{array}$ & 12 & 60 & 24 & 4 & 100 \\
3 & $\begin{array}{l}\text { Sumber } \\
\text { bahan }\end{array}$ & 16 & 60 & 20 & 4 & 100 \\
& & & & & \\
\end{tabular}




\begin{tabular}{|c|c|c|c|c|c|c|}
\hline & $\begin{array}{l}\text { pupuk dari } \\
\text { limbah }\end{array}$ & & & & & \\
\hline 4 & $\begin{array}{l}\text { Kandungan } \\
\text { hara pupuk } \\
\text { organik }\end{array}$ & 12 & 60 & 20 & 8 & 100 \\
\hline 5 & $\begin{array}{l}\text { Jenis-jenis } \\
\text { pupuk } \\
\text { organik }\end{array}$ & 12 & 68 & 16 & 4 & 100 \\
\hline & Rata-rata & 14,4 & 60,0 & 20,8 & 4,8 & 100 \\
\hline
\end{tabular}

Keterangan: $\mathrm{STT}=$ sangat tidak tahu; $\mathrm{TH}=$ tidak tahu; $\mathrm{T}=$ tahu; ST = sangat tahu.

Hasil evaluasi awal tingkat pengetahuan terhadap 25 peserta pelatihan tentang pupuk organik diperoleh skor pengetahuan awal peserta (Gambar 5), seperti berikut:

Skor total $=270$

Skor tertinggi $=500$

Skor terendah $=125$

Dengan demikian, maka rata-rata tingkat pengetahuan awal peserta tentang pupuk organik di Desa Bualo Kecamatan Paguyaman Kabupaten Boalemo adalah: $270 / 500 \times 100 \%=54,0 \%$. Berdasarkan Garis Continuum (Gambar 5) dapat diketahui bahwa pengetahuan awal peserta pelatihan termasuk dalam kategori tahu tentang pupuk organik. Secara ilmiah dan fakta tersebut, maka Tim PPDM dan pemateri pelatihan pembuatan pupuk organik melakukan penajaman dan fokus terhadap peningkatan pengetahuan dan secara bertahap diikuti dengan peningkatan ketrampilan pembuatan pupuk organik.

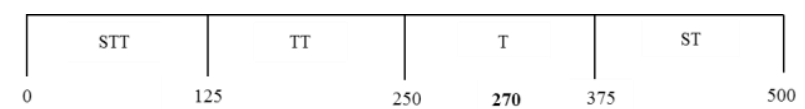

Gambar 5. Garis Continuum Pengetahuan Awal Peserta tentang Pupuk Organik.

Selama kegiatan pelatihan, animo dan respon peserta pelatihan cukup tinggi yang ditunjukkan oleh banyaknya pertanyaan yang diajukan oleh peserta kepada pemateri. Pertanyaan yang paling menonjol adalah terkait tata cara pembuatan pupuk organik dan kesetaraan pupuk organik dengan pupuk anorganik (Urea dan Phonska) jika nanti diterapkan di lahan pertanian. Setelah mendapat jawaban dari pemateri, maka optimisme peserta terhadap keberlanjutan kegiatan ini semakin nampak karena selain mudah membuatnya juga ketersediaan bahan baku pupuk organik yang melimpah di Desa Bualo saat ini.
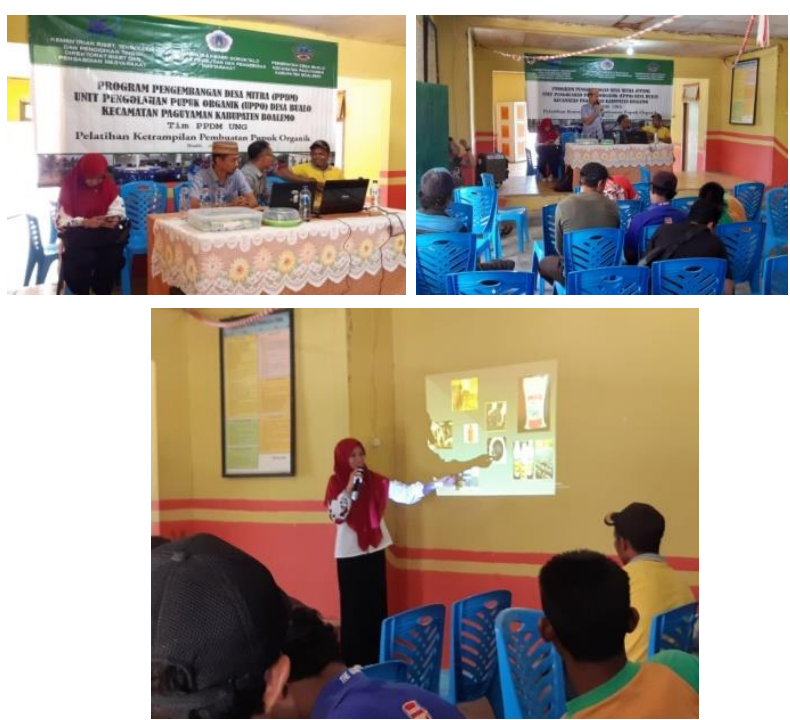

Gambar 6. Kegiatan Pelatihan Pembuatan Pupuk Organik di Desa Bualo Kecamatan Paguyaman Kabupaten Boalemo.

Kegiatan pendampingan pembuatan pupuk organik dan penggunaan sarana dan prasarana pembuatan pupuk organik telah dilakukan (Gambar 6) di Rumah Kompos UPPO Milik Kelompok Tani Sumber Rezeki dengan peserta utama adalah anggota kelompok tani yang menjadi mitra PPDM, dan peserta tambahan dari warga Desa Bualo lainnya, terutama perangkat desa yang juga berprofesi sebagai petani setempat. Pembuatan pupuk organik dengan memanfaatkan bahan baku lokal setempat yaitu: limbah jagung, kotoran ternak (feases), urin, bungkil kakao, EM4, starter gula dan air. Pembuatan pupuk organik dengan melakukan proses fermentasi dan pengomposan yang diikuti oleh peserta dipandu oleh Tim PPDM dan Penyuluh Pertanian Setempat. Hasil yang diperoleh cukup memuaskan dengan proses pengomposan yang berjalan dengan baik (Gambar 7). Selama proses fermentasi dan pengomposan, dilakukan monitoring secara berkala untuk memperoleh hasil pupuk organik yang ditetapkan.
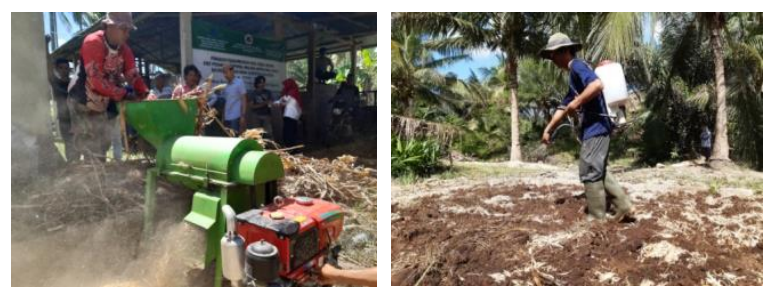

Gambar 6. Kegiatan Pendampingan Pembuatan Pupuk Organik di Desa Bualo Kecamatan Paguyaman Kabupaten Boalemo. 

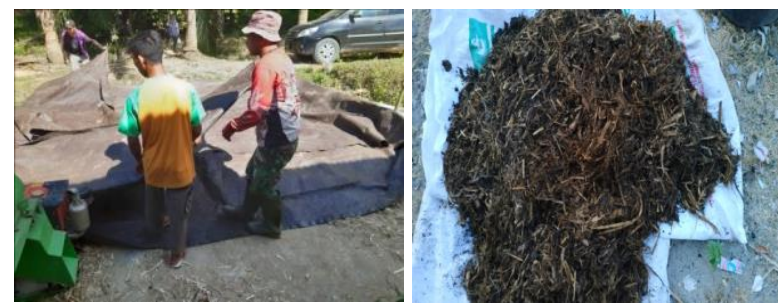

Gambar 7. Kegiatan Fermentasi dan Pengomposan Pupuk Organik di Desa Bualo Kecamatan Paguyaman Kabupaten Boalemo.

Setelah dilakukan pemberian materi dan pendampingan pembuatan pupuk organik, maka dilaksanakan test akhir tingkat pengetahuan peserta tentang pupuk organik dan hasilnya disajikan pada Tabel 5, 6, 7 dan Tabel 8. Hasil pengujian validitas instrumen pengetahuan awal peserta terhadap pupuk organik menunjukkan bahwa instrumen yang digunakan untuk mengetahui tingkat pengetahuan awal peserta tentang pupuk organik di Desa Bualo Valid. Hal ini ditunjukkan oleh nilai korelasi mendekati 1 pada semua item yang diuji, yaitu antara $0,760-0,924$ dengan probabilitas korelasi rata-rata 0,000 (signifikan).

Tabel 5. Hasil Uji Validitas Instrumen Tingkat Pengetahuan Akhir Peserta Setelah Pelatihan.

\begin{tabular}{|c|c|c|c|c|}
\hline $\begin{array}{l}\mathbf{N} \\
\mathbf{o}\end{array}$ & $\begin{array}{c}\text { Korela } \\
\text { si } \\
\text { Antara }\end{array}$ & $\begin{array}{c}\text { Nilai } \\
\text { Korelasi } \\
\text { (Pearsons } \\
\text { Correlation } \\
\text { s) }\end{array}$ & $\begin{array}{c}\text { Probabilit } \\
\text { as } \\
\text { Korelasi } \\
\text { [sig.(2- } \\
\text { tailed)] }\end{array}$ & $\underset{\mathrm{n}}{\text { Kesimpula }}$ \\
\hline 1 & $\begin{array}{l}\text { Item } \\
\text { No. } 1 \\
\text { dengan } \\
\text { Total }\end{array}$ & 0,760 & 0,000 & Valid \\
\hline 2 & $\begin{array}{l}\text { Item } \\
\text { No. } 2 \\
\text { dengan } \\
\text { Total }\end{array}$ & 0,796 & 0,000 & Valid \\
\hline 3 & $\begin{array}{l}\text { Item } \\
\text { No. } 3 \\
\text { dengan } \\
\text { Total }\end{array}$ & 0,918 & 0,000 & Valid \\
\hline 4 & $\begin{array}{l}\text { Item } \\
\text { No. } 4 \\
\text { dengan } \\
\text { Total }\end{array}$ & 0,909 & 0,000 & Valid \\
\hline 5 & $\begin{array}{l}\text { Item } \\
\text { No. } 5 \\
\text { dengan } \\
\text { Total }\end{array}$ & 0,924 & 0,000 & Valid \\
\hline
\end{tabular}

Hasil pengujian reliabilitas instrumen pengetahuan akhir peserta tentang pupuk organik menunjukkan bahwa nilai Cronbach's Alpha sebesar 0,819. Hal ini menunjukkan bahwa instrumen yang digunakan untuk mengetahui pengetahuan awal peserta tentang pupuk organik di Desa Bualo Reliabel (Tabel 6).
Tabel 6. Nilai Cronbach's Alpha Instrumen Tingkat Pengetahuan Awal Peserta Sebelum Pelatihan.

\begin{tabular}{cc}
\hline \multicolumn{2}{c}{ Tingkat Pengetahuan Awal Peserta } \\
\hline Cronbach's Alpha & N of Items \\
\hline .819 & 6 \\
\hline
\end{tabular}

Berdasarkan Tabel 7, rata-rata mayoritas peserta pelatihan sudah tahu terkait pengetahuannya tentang pupuk organik. Pesentase peserta yang tahu dan bahkan sangat tahu terkait pupuk organik sebesar $88.0 \%$. Sementara itu, peserta yang tidak tahu persentasenya tinggal sebesar $12,0 \%$ saja.

Tabel 7. Persentase Jawaban Peserta tentang Pupuk Organik Setelah Pelatihan.

\begin{tabular}{|c|c|c|c|c|c|c|}
\hline \multirow{2}{*}{$\begin{array}{l}\mathbf{N} \\
\mathbf{0}\end{array}$} & \multirow{2}{*}{$\begin{array}{c}\text { Item } \\
\text { Pertanyaan }\end{array}$} & \multicolumn{4}{|c|}{$\begin{array}{l}\text { Persentase jawaban } \\
\text { pengetahuan peserta }\end{array}$} & \multirow[t]{2}{*}{ Jumlah } \\
\hline & & STT & TH & $\mathbf{T}$ & ST & \\
\hline 1 & $\begin{array}{l}\text { Pengertian } \\
\text { pupuk } \\
\text { organik }\end{array}$ & - & 8 & 88 & 4 & 100 \\
\hline 2 & $\begin{array}{l}\text { Penggunaan } \\
\text { pupuk } \\
\text { organik }\end{array}$ & - & 12 & 80 & 8 & 100 \\
\hline 3 & $\begin{array}{l}\text { Sumber } \\
\text { bahan pupuk } \\
\text { dari limbah }\end{array}$ & - & 16 & 72 & 12 & 100 \\
\hline 4 & $\begin{array}{l}\text { Kandungan } \\
\text { hara pupuk } \\
\text { organik }\end{array}$ & - & 12 & 64 & 24 & 100 \\
\hline 5 & $\begin{array}{l}\text { Jenis-jenis } \\
\text { pupuk } \\
\text { organik }\end{array}$ & - & 12 & 68 & 20 & 100 \\
\hline & Rata-rata & - & 12,0 & 74,4 & 13,6 & 100 \\
\hline
\end{tabular}

Keterangan: STT $=$ sangat tidak tahu; $\mathrm{TH}=$ tidak tahu; $\mathrm{T}=$ tahu; ST = sangat tahu.

Apabila dibandingkan dengan sebelum pelatihan (Tabel 8), maka jumlah peserta yang mengetahui tentang pupuk organik sebelum pelatihan berlangsung hanya sebesar $25,6 \%$ dan setelah selesai mengikuti pelatihan dan pendampingan pembuatan pupuk organik, maka jumlah peserta yang tahu tentang pupuk organik tersebut mengalami peningkatan dari hanya sebesar $25,6 \%$ menjadi $88.0 \%$.

Tabel 8. Persentase Tingkat Pengetahuan Peserta tentang Pupuk Organik Sebelum dan Setelah Pelatihan.

\begin{tabular}{clcc}
\hline \multirow{2}{*}{$\begin{array}{l}\text { Item Pertanyaan } \\
\text { o }\end{array}$} & $\begin{array}{c}\text { Sebelum } \\
\text { Materi }\end{array}$ & $\begin{array}{c}\text { Setelah Materi } \\
\text { Tahu dan } \\
\text { sangat } \\
\text { tahu (\%) }\end{array}$ & $\begin{array}{c}\text { Tahu dan } \\
\text { sangat tahu } \\
(\%)\end{array}$ \\
\hline 1 & $\begin{array}{l}\text { Pengertian pupuk } \\
\text { organik }\end{array}$ & 28 & 92 \\
2 & $\begin{array}{l}\text { Penggunaan } \\
\text { pupuk organik }\end{array}$ & 28 & 88 \\
3 & $\begin{array}{l}\text { Sumber bahan } \\
\text { pupuk dari limbah }\end{array}$ & 28 & 84 \\
4 & $\begin{array}{l}\text { Kandungan hara } \\
\text { pupuk organik }\end{array}$ & 28 & 88 \\
\end{tabular}


5 Jenis-jenis pupuk organik

Rata-tata

20

88

\begin{tabular}{rrr}
\hline Rata-tata & 25,6 & $\mathbf{8 8 , 0}$ \\
\hline
\end{tabular}

Hasil evaluasi akhir tingkat pengetahuan peserta pelatihan tentang pupuk organik diperoleh skor pengetahuan akhir (Gambar 8), seperti berikut:

Skor total $=377$

Skor tertinggi $=500$

Skor terendah $=125$

Dengan demikian, maka rata-rata tingkat pengetahuan awal peserta tentang pupuk organik di Desa Bualo Kecamatan Paguyaman Kabupaten Boalemo adalah: $377 / 500 \times 100 \%=75,4 \%$. Berdasarkan Garis Continuum (Gambar 8) dapat diketahui bahwa pengetahuan awal peserta pelatihan termasuk dalam kategori sangat tahu tentang pupuk organik.

\begin{tabular}{|c|c|c|c|c|c|c|}
\hline STT & & TT & & $\mathrm{T}$ & & ST \\
\hline 0 & 125 & & 250 & & 375 & 377 \\
\hline
\end{tabular}

Gambar 8. Garis Continuum Pengetahuan Awal Peserta tentang Pupuk Organik.

\section{KESIMPULAN}

Kegiatan IB terhadap sapi induk dapat menjadi salah satu solusi untuk meningkatkan populasi sapi di Desa Bualo Kecamatan Paguyaman Kabupaten Boalemo. Jumlah sapi induk yang berhasil bunting sudah sebanyak 12 ekor dan kegiatan IB sangat potensial dilanjutkan ke depan guna peningkatan populasi ternak sapi berdasarkan animo petani/peternak, ketersediaan pakan dan luas lahan pertanian sebagai sumber pakan yang memadai. Kegiatan pelatihan dan pendampingan kepada petani di Kelompok Tani Sumber Rezeki telah mampu meningkatkan tingkat pengetahuan tentang pupuk organik. Pada awalnya, masih sebanyak $74,4 \%$ peserta pelatihan tidak tahu tentang pupuk organik sementara setelah meningkuti pelatihan dan pendampingan menjadi sebesar $88,0 \%$ peserta pelatihan yang sudah tahu tentang pupuk organik, sisanya hanya tinggal sebesar $12,0 \%$ saja yang belum tahu tentang pupuk organik. Guna menjamin keberlanjutan pengolahan pupuk organik ke depan, maka perlu diintensifkan pendampingan kepada petani, baik oleh penyuluh pertanian setempat maupun dari perguruan tinggi, terutama Fakultas Pertanian. Harapan ke depan, Desa Bualo bisa menjadi desa mandiri berbasis pertanian organik dan setra peternakan sapi potong, sehingga dapat keluar dari 40 desa prioritas nasional dan status desa tertinggal.

\section{UCAPAN TERIMA KASIH}

Terima kasih disampaikan kepada Kementrian Riset, Teknologi dan Pendidikan Tinggi yang telah mendanai kegiatan pengabdian kepada masyarakat melalui Program Pengembangan Desa Mitra (PPDM) tahun anggaran 2019 yang salah satu luarannya adalah artikel jurnal ini. Kepada Bapak Agustinus Mointi, SE, MM terima kasih atas asistensi analisis data dalam software SPSS.

\section{DAFTAR PUSTAKA}

Baba, H., Hastang., \& M. Risal. (2015). Hambatan Pelaksanaan Teknologi Ib Sapi Bali di Kabupaten Barru. Dalam Seminar Nasional Agribisnis III "Inovasi Agribisnis untuk Peningkatan Pertanian Berkerlanjutan (160164), Semarang, Indonesia: Program Studi Agribisnis Fakultas Peternakan dan Pertanian, Universitas Diponegoro dan Perhimpunan Ekonomi Pertanian Indonesia (Perhepi).

BPS Kabupaten Boalemo. (2018). Kabupaten Boalemo dalam Angka Tahun 2018. Badan Pusat Statistik Kabupaten Boalemo, Tilamuta.

Badan Koordinasi Penyuluhan Pertanian. (2019). Gabungan Kelompok Tani Dwikarya. https://bakorluh.gorontaloprov.go.id/simbanglu h/gapoktandetail/542/?gapoktan=DwiKarya

Hastuti, D. (2008). Tingkat Keberhasilan Inseminasi Buatan Sapi Potong di Tinjau dari Angka Konsepsi dan Service Per Conception. Mediagro, 4(1), 12- 20.

Hadipurwanta \& Kuswanto. (2017). Kajian Pengetahuan dan Sikap Petani terhadap Penggunaan Bahan Organik Pada Usahatani Padi Sawah di Desa Negararatu, Kecamatan Natar, Kabupaten Lampung Selatan. Prosiding Seminar Nasional Agroinovasi Spesifik Lokasi Untuk Ketahanan Pangan Pada Era Masyarakat Ekonomi ASEAN. http://lampung.litbang.pertanian.go.id/ind/ images/stories/publikasi/prosiding_1_2017/67.k ajianpengetahuantrikusnanto.pdf

Inounu, I. (2014). Upaya Meningkatkan Keberhasilan Inseminasi Buatan pada Ternak Ruminansia Kecil. Wartazoa, 24(4), 201-209.

Nurdin, M. Baruwadi, F. Zakaria, R. Yusuf, D. A Rachim, Suwarno dan Darmawan. (2009). Penelitian dan Pengembangan Komoditas Unggulan Berdasarkan Potensi Sumberdaya Lahan melalui Analisis Kesesuaian Lahan dan Pewilayahan Komoditas Unggulan di Kabupaten Boalemo. Laporan Penelitian. Kerjasama Bappeda Kabupaten Boalemo dengan Pusat Kajian Pertanian Tropis (PKPT) Universitas Negeri Gorontalo, Tilamuta.

Nuro F, D. Priadi, dan E. S. Mulyaningsih. (2016). Efek Pupuk Organik terhadap Sifat Kimia Tanah dan Produksi Kangkung Darat (Ipomoea reptans Poir.). Prosiding Seminar Nasional Hasil-Hasil PPM IPB 2016. Hal: 29-39.

Pemerintah Desa Bualo. (2018). Rencana Pembangunan Jangka Menengah (RPJM) Desa Bualo Tahun 2017-2022. Pemerintah Desa Bualo Kecamatan Paguyaman Kabupaten Boalemo, Bualo.

Sugiyono. 2013. Metode Penelitian Pendidikan Pendekatan Kuantitatif, Kualitatif \& R\&D. Bandung: Alfabeta.

Sabran. (2015). Pengaruh Tingkat Keberhasilan Inseminasi Buatan (IB) terhadap Peningkatan Populasi Sapi Potong di Kabupaten Bantaeng (Studi Kasus di Kecamatan Gantarangkeke Kabupaten Bantaeng). Skripsi Jurusan Ilmu 
Peternakan Fakultas Sains dan Teknologi Universitas Islam Negeri Alauddin, Makassar. 